\title{
Combining genetic and physiological data to identify predictors of lifetime reproductive success and the effect of selection on these predictors on underlying fertility traits
}

\author{
N. A. Dennis, ${ }^{\star 1}$ K. Stachowicz, ${ }^{\star}$ B. Visser, ${ }^{*}$ F. S. Hely, ${ }^{\star}$ D. K. Berg,† N. C. Friggens,† P. R. Amer, ${ }^{*}$ S. Meier,§ \\ and C. R. Burke§ \\ *AbacusBio Limited, PO Box 5585, Dunedin 9058, New Zealand \\ †AgResearch Ltd., Ruakura Research Centre, Private Bag 3123, Hamilton, New Zealand \\ łUMR 0791 Modélisation Systémique Appliquée aux Ruminants, INRA, AgroParisTech, Université Paris-Saclay, F-75005 Paris, France \\ §DairyNZ Limited, Private Bag 3221, Hamilton 3240, New Zealand
}

\begin{abstract}
Fertility of the dairy cow relies on complex interactions between genetics, physiology, and management. Mathematical modeling can combine a range of information sources to facilitate informed predictions of cow fertility in scenarios that are difficult to evaluate empirically. We have developed a stochastic model that incorporates genetic and physiological data from more than 70 published reports on a wide range of fertilityrelated traits in dairy cattle. The model simulates pedigree, random mating, genetically correlated traits (in the form of breeding values for traits such as hours in estrus, estrous cycle length, age at puberty, milk yield, and so on), and interacting environmental variables. This model was used to generate a large simulated data set (200,000 cows replicated 100 times) of herd records within a seasonal dairy production system (based on an average New Zealand system). Using these simulated data, we investigated the genetic component of lifetime reproductive success (LRS), which, in reality, would be impractical to assess empirically. We defined LRS as the total number of times, during her lifetime, a cow calved within the first $42 \mathrm{~d}$ of the calving season. Sire estimated breeding values for LRS and other traits were calculated using simulated daughter records. Daughter pregnancy rate in the first lactation (PD_1) was the strongest single predictor of a sire's genetic merit for LRS $\left(\mathrm{R}^{2}=0.81\right)$. A simple predictive model containing PD_1, calving date for the second season and calving rate in the first season provided a good estimate of sire LRS $\left(R^{2}=0.97\right)$. Daughters from sires with extremely high $(\mathrm{n}=99,995$ daughters, sire LRS $=+0.70)$ or low $(\mathrm{n}=99,635$ daughters, sire LRS $=$ -0.73) LRS estimated breeding values were compared
\end{abstract}

Received June 19, 2017.

Accepted December 4, 2017.

${ }^{1}$ Corresponding author: ndennis@abacusbio.co.nz over a single generation. Of the 14 underlying component traits of fertility, 12 were divergent between the 2 lines. This suggests that genetic variation in female fertility has a complex and multifactorial genetic basis. When simulated phenotypes were compared, daughters of the high LRS sires (HiFERT) reached puberty 44.5 d younger and calved $\sim 14 \mathrm{~d}$ younger at each parity than daughters from low LRS sires (LoFERT). Despite having a much lower genetic potential for milk production $(-400 \mathrm{~L} /$ lactation $)$ than LoFERT cows, HiFERT cows produced $33 \%$ more milk over their lifetime due to additional lactations before culling. In summary, this simulation model suggests that LRS contributes substantially to cow productivity, and novel selection criteria would facilitate a more accurate prediction at a younger age.

Key words: reproduction, genetic evaluation, simulation model

\section{INTRODUCTION}

Reproduction is a key driver of the profitability of dairy farming. Regardless of geography or production system, improving female fertility in dairy cattle improves profitability by reducing costs associated with mating and early culling and by increasing the length of the cow's productive lifetime (Veerkamp et al., 2002; González-Recio et al., 2004; Meadows et al., 2005; De Vries, 2006). Genetic selection is an effective method for producing long-term and compounding improvements in dairy cow fertility (Pryce and Veerkamp, 2001; Pryce et al., 2014). However, evaluating many traits for genetic selection via on-farm recording can be cost prohibitive and time consuming. Typically, phenotypes derived from existing industry records (e.g., gestation length and mating submission rate) are used as genetic selection criteria, but these can be highly variable due to random and systematic environmental effects and inaccurate recording. Manipulative experimentation with 
novel selection criteria (e.g., hormone assays, behavioral data) is extremely costly, particularly in the context of genetic evaluation because thousands of records are required. An alternative, or supplementary approach, is to use mathematical modeling to simulate the recording of novel selection phenotypes in an industry setting. This method combines existing knowledge of the genetic and environmental contributions to variation in female fertility into a stochastic simulation that can predict the outcomes of different scenarios.

Reproductive success relies on complex interactions between genetics, physiology, and management. For example, the inter-calving interval is affected by how soon the postpartum cow resumes ovulation and displaying overt estrus, the strength and regularity of her estrus events, milk yield, body fat, the probabilities of conception and pregnancy loss, and the length of gestation. Many of these underlying drivers of fertility are heritable and modified by management and environmental factors (reviewed in Royal et al., 2000a). In addition, a cow's previous history such as growth as a heifer, age at puberty, calving difficulty, and hormonal treatments can affect subsequent fertility.

Here, we describe the development of a stochastic simulation model driven by genetic, physiological, and management parameters derived from over 70 published studies. This model is based on the average seasonalpastoral system in New Zealand, where, to match feed demand with pasture growth, the whole herd calves in early spring and is rebred within a fixed period (generally $12 \mathrm{wk}$ ) to maintain an annual calving cycle. Cows that conceive early in the mating season (and therefore calve early in the calving season) are the most desirable because they have a greater number of DIM and a longer recovery period between calving and the beginning of the next mating season. Cows that are not successfully bred in this fixed mating season represent a net cost to the seasonal-pastoral system and are culled.

We used this model to generate a large simulated data set $(200,000$ cows per simulation with simulations replicated 100 times) and investigated a range of combinations of measurements for predicting the genetic merit of sires for lifetime reproductive success (LRS).

During this simulation, we also investigated the effect that sires with extreme genetic merit (either very high or very low) for fertility can have on daughter production and reproduction.

\section{MATERIALS AND METHODS}

\section{Model Description}

A stochastic fertility model was developed to simulate detailed lifetime phenotypic herd records (up to 5 pari- ties) for dairy cattle in a New Zealand seasonal calving herd. The model is composed of 3 modules (Figure 1). A genetic module with specified genetic variance and covariance inputs is used to parameterize a simple pedigree with correlated genetic drivers of fertility, a heifer development module simulates outcomes from birth until first calving, and the milking cow module simulates outcomes from first calving until death or culling.

The model has been programmed in $\mathrm{R}$ ( $\mathrm{R}$ Core Team, 2016) using add-on packages: "corpcor" (Schäfer et al., 2015), "data.table" (Dowle et al., 2015), "gdata" (Warnes et al., 2015), "MASS" (Venables and Ripley, 2002), "plyr" (Wickham, 2011), "reshape" (Wickham, 2007), and "runuran" (Leydold and Hörmann, 2015).

\section{Model Parameters}

Important management and environmental parameters in a seasonal pastoral system are listed in Table 1. We conducted a literature review to obtain estimates of 14 underlying drivers of fertility, with a focus on New Zealand cattle (Table 2). We used published genetic correlations to emulate genetic relationships among underlying fertility driving traits (Table 3 ). Where necessary, inputs were adjusted to reflect the high proportion of Holstein-Friesian $\times$ Jersey crossbreds present in New Zealand systems.

\section{Genetic Module: Simulation of Driving Variable Values}

A key component of the model is the simulation of underlying genetic variation in fertility for a set of cows organized in a simple pedigree structure (1 generation). This pedigree structure is important for simulating the underlying genetic variation among cows and also facilitates a genetic analysis of simulated data to infer genetic properties for aggregate genetic traits. The structure was chosen to facilitate efficient computation of accurate genetic merit of aggregate genetic traits. Thus, unrelated sires and dams were simulated in each replicate to generate a single generation of cows with phenotypes in 200 paternal half sib groups of 1,000 . The sire and dam genetic variables along with a Mendelian sampling term are combined to generate a true breeding value (TBV) as follows:

$\mathrm{TBV}_{i}^{t^{\prime}}=\sum_{j=1}^{t^{\prime}}\left(\frac{\delta_{i}^{t} \lambda_{t^{\prime}, j} \sqrt{h_{t^{\prime}}^{2} \sigma_{t^{\prime}}^{2}}+\varepsilon_{i}^{t} \lambda_{t^{\prime}, j} \sqrt{h_{t^{\prime}}^{2} \sigma_{t^{\prime}}^{2}}}{2}+\phi_{i}^{t} \lambda_{t^{\prime}, j} \sqrt{\frac{1}{2} h_{t^{\prime}}^{2} \sigma_{t^{\prime}}^{2}}\right)$,

where $t^{\prime}$ is the trait expressed in the $i$ th simulated cow, and $\delta_{i}^{t^{\prime}}, \varepsilon_{i}^{t^{\prime}}$ and $\phi_{i}^{t^{\prime}}$ are independent random standard 
Table 1. Nongenetic parameter inputs based on the average industry values for New Zealand dairy cows

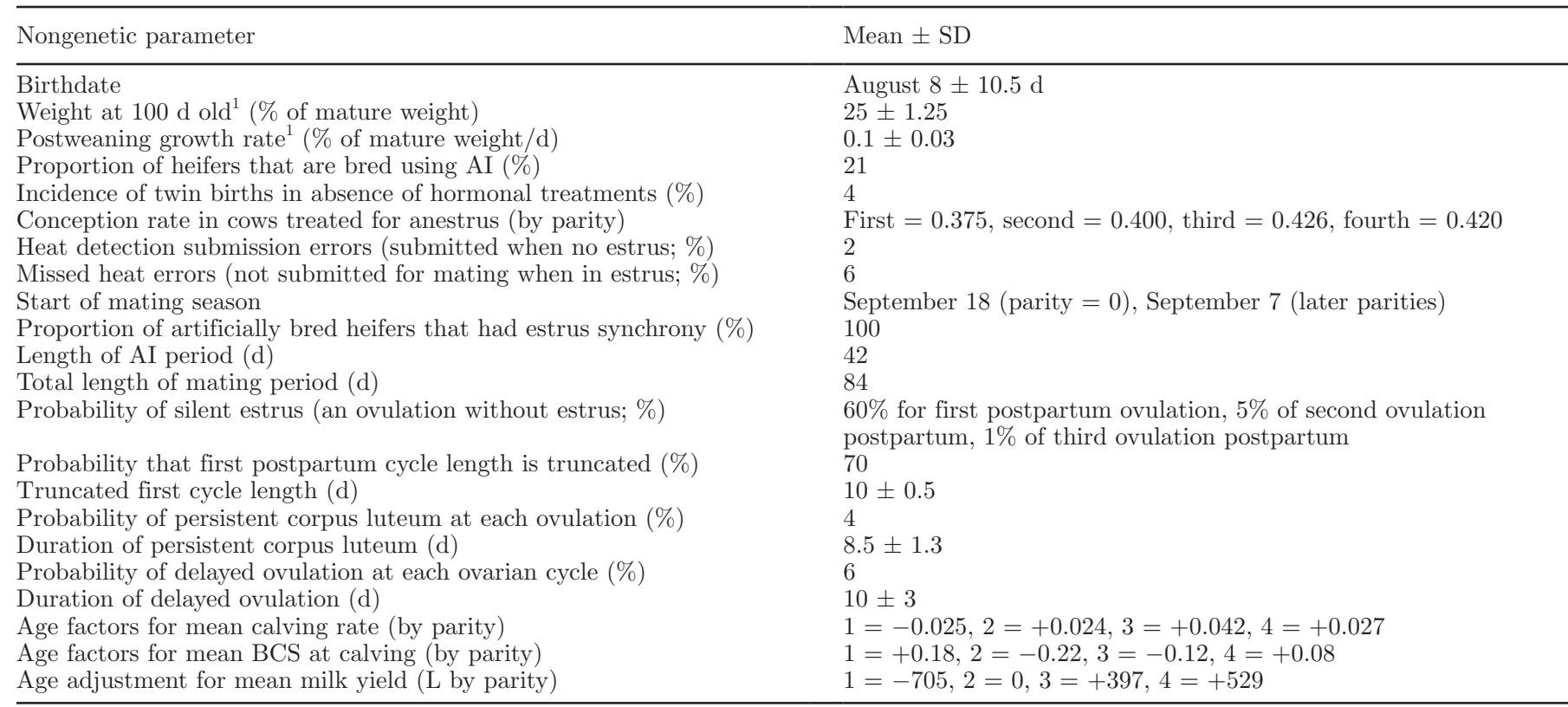

${ }^{1}$ The average New Zealand herd has a high proportion of crossbred animals (around 47\%). To accommodate different breeds in the model, weight and growth rate variables are simulated as a proportion of mature live weight.

normal deviates corresponding to the sire, dam, and Mendelian sampling components of the genetic variation. Initially, traits $t^{\prime}$ are defined separately as being maternal or direct in their mode of expression, and then subsequently when both maternal and direct ge- netic effects are aggregated to contribute to the trait phenotype below we index traits with a $t$. Genetic variation in each trait is characterized whereby $h_{t^{\prime}}^{2}$ is the heritability and $\sigma_{t^{\prime}}^{2}$ is the phenotypic variance of the target driving variable traits $t^{\prime}$ (values presented in

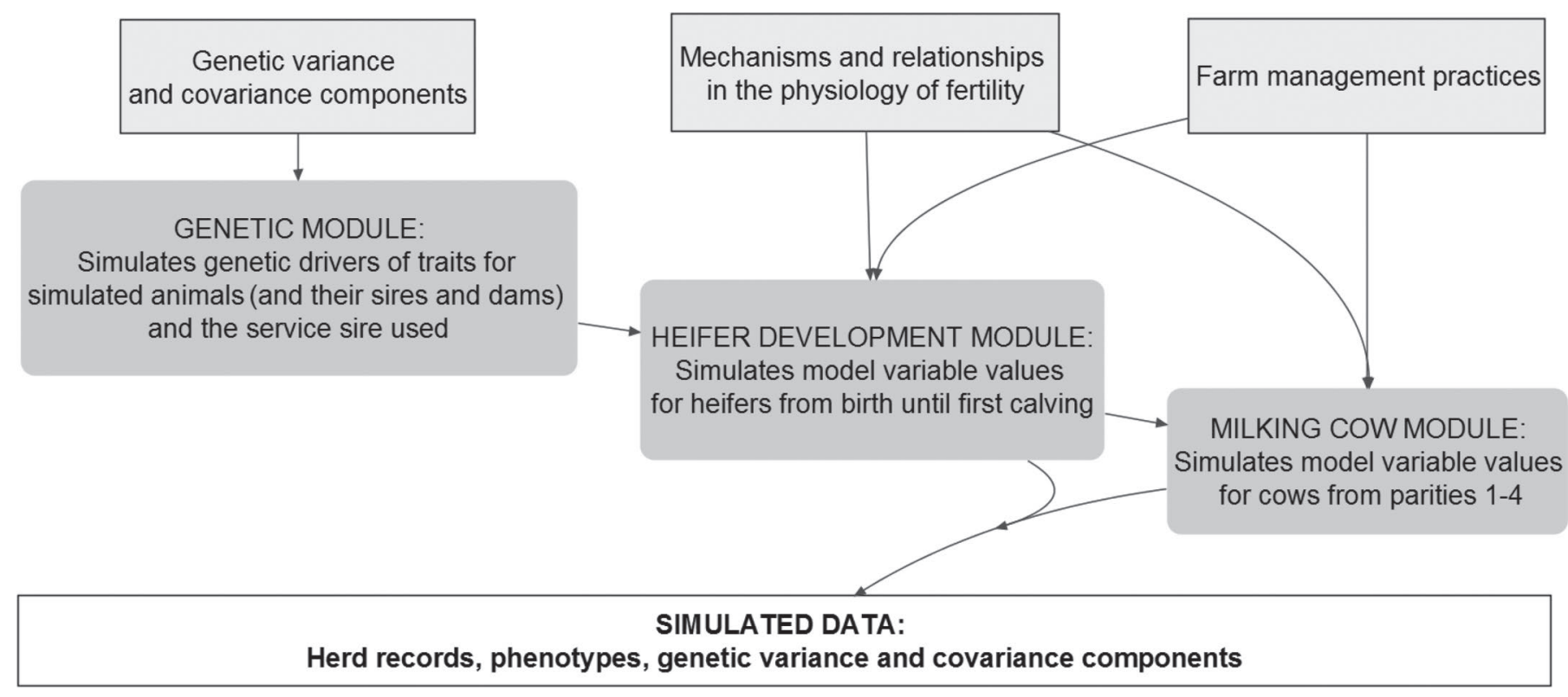

Figure 1. Components of the stochastic fertility model. The stochastic model has 3 modules. The genetic module uses specified genetic variances and covariances to construct a simple pedigree and simulate genetic drivers of fertility. The heifer development module simulates physiological and environmental factors from birth until first calving, and the milking cow module simulates fertility factors from first calving until death or culling. 
Table 2). The correlation structure among the traits is simulated using $\lambda_{t^{\prime}, j}$, which are the elements of the Cholesky decomposition (Ripley, 1987) of the genetic correlation matrix (presented in Table 3) among traits in row $t^{\prime}$ corresponding to the trait for which the specific TBV is being simulated for, and accumulating independent components of variation indexed $j$ are aggregated into combinations that mimic the full genetic variance covariance structure of the traits (the desired correlations are shown in Table 3) and the appropriate genetic covariance among the half sib relatives simulated as part of the pedigree structure.

\section{Simulating Herd Records}

The TBV simulated as above are combined with physiological and environmental factors to simulate phenotypes $(P)$ for a subset of traits denoted $t$ including both directly and maternally (if relevant) inherited genetic components, as shown below:

$$
P_{i}^{t}=\mu_{t}+\mathrm{TBV}_{i}^{t}+\sum_{k} \beta_{k}^{t}+e_{i}^{t},
$$

where $\mu$ is the mean for trait $t$ (e.g., whole lactation milk yield) and TBV is the TBV value generated using Equation [1] for cow $i$ (calculated in Equation [1]). Trait specific adjustments known to affect the phenotype are denoted as $\beta$. For example, the estrous cycle length phenotype has $k=4$ adjustments: an adjustment for milk yield, and adjustments for incidences of truncated cycle length, a persistent corpus luteum, and delayed ovulation. The adjustments for each simulated phenotype with genetic inputs can be found in Supplemental Table S1 (https://doi.org/10.3168/jds.2017-13355).

For traits affected by calf genetics (e.g., gestation length and calving difficulty), this equation is adapted as follows:

$$
P_{i}^{t}=\mu_{t}+\mathrm{TBV}_{i}^{t}+\operatorname{calfTBV}_{i}^{t}+\sum_{k} \beta_{k}^{t}+e_{i}^{t}
$$

where calfTBV represents a simulated TBV value (calculated as per Equation [1], using the TBV of the dam and a randomly allocated service sire) for the calf in gestation for the trait $t$ (e.g., the gestation length). The gestation length phenotype has $k=3$ adjustments, parity $(-1.6 \mathrm{~d}$ for first parity), sex of the in utero calf $(+1.3 \mathrm{~d}$ for bull calves), and number of calves in utero ( $-5.2 \mathrm{~d}$ for twin pregnancies). The random environmental effect, $e$, is calculated as follows:

$$
e_{i}^{t}=\phi_{i}^{t} \sqrt{\left(1-h_{d t}^{2}-h_{m t}^{2}\right) \sigma_{t}^{2}},
$$

Table 2. Driving variables derived from public literature

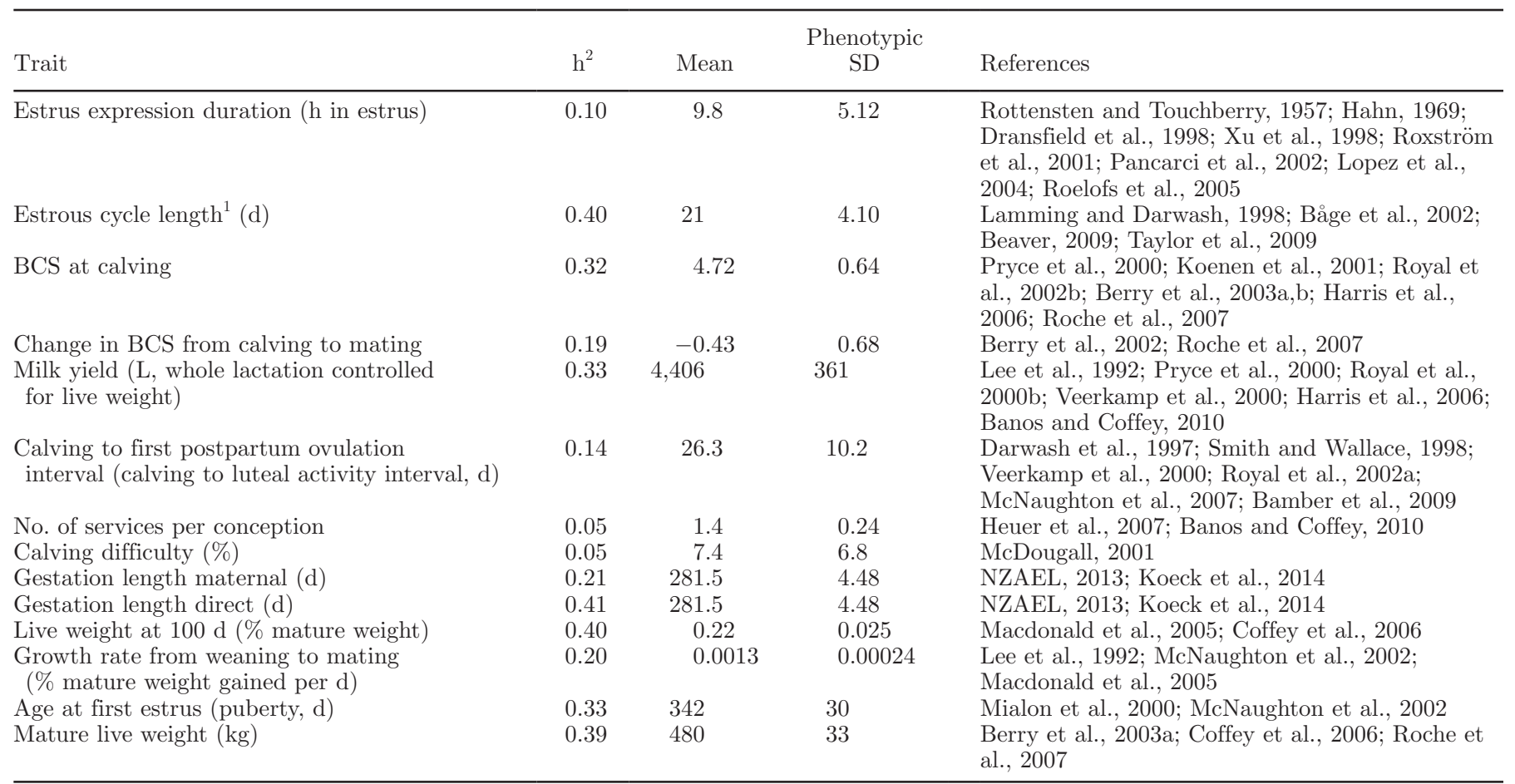

\footnotetext{
${ }^{1}$ No cattle data were available on the genetic parameters of estrous cycle length, so other species have been used.
} 
where $\phi_{i}^{t}$ is an independent random standard normal deviate drawn for animal $i, h_{d t}^{2}$ and $h_{m t}^{2}$ are the direct and maternal heritabilities and $\sigma_{t}^{2}$ is the phenotypic variance of the TBV for trait $t$. The random environmental effect is calculated for each phenotype independently (i.e., the random environmental effect is not constant per animal during its whole life).

\section{Heifer Development Module: Simulation of Heifer Phenotypes}

Recorded phenotypes are simulated using a set of phenotypes in vector $\mathbf{P}$ (which are generated in Equation 2), with $\varepsilon$ being the vector of nongenetic model parameters listed in Table 1 (e.g., date of start of mating season) according to a generalized functional relationship as follows:

$$
\text { Recorded phenotype }=f(\mathbf{P}, \varepsilon) .
$$

An example of the interaction of phenotypes is illustrated in Figure 2 and specific inputs of the simulated phenotypes are given in Supplemental Table S2 (https://doi.org/10.3168/jds.2017-13355). The simulation begins with the random assignment of a birthdate for every heifer, assuming the birthdates of heifers kept as replacements follow a normal distribution with a mean date of August 8 and a standard deviation of 10.5 d. Calf growth is simulated using variables from the genetic module. Calves growing exceptionally slowly (either weighing less than $15 \%$ of mature weight at 100 $\mathrm{d}$ old or growing at less than $0.015 \%$ mature weight per day) were removed from the herd.

We simulated the probability of the onset of puberty (first estrus) as a function of live weight and underlying genetics (the TBV for age at puberty); the probability of puberty onset increases substantially once BW reached $45 \%$ of mature live weight. The timing of subsequent estrus events was defined using the heifer's estrus cycle length.

The first mating date for a heifer is defined as the first estrus after the start of the mating season, unless the heifer was randomly allocated to estrus synchronization for artificial breeding (in which case the first mating default is the first day of the mating season). A heifer mated during a natural estrus is assumed to have a conception rate of $99 \%$. A synchronized mating is assumed to have a lower conception rate and higher twinning rate compared with natural matings $(-11$ and $+10.3 \%$, respectively; Vasconcelos et al., 2001). Heifers mated during their pubertal estrus were simulated with a reduced probability of conception $(-34.3 \%)$ and any matings that occurred before pubertal onset (e.g., 
estrus synchrony in a pre-pubertal heifer) were unsuccessful. Conception was also affected by the incidence of cystic ovaries, which was randomly assigned to $4 \%$ of estrus events.
The survival of the pregnancy is randomly determined for first and subsequent matings using a pregnancy survival curve, which distributes the risk of pregnancy loss throughout pregnancy as shown in Figure 3. The
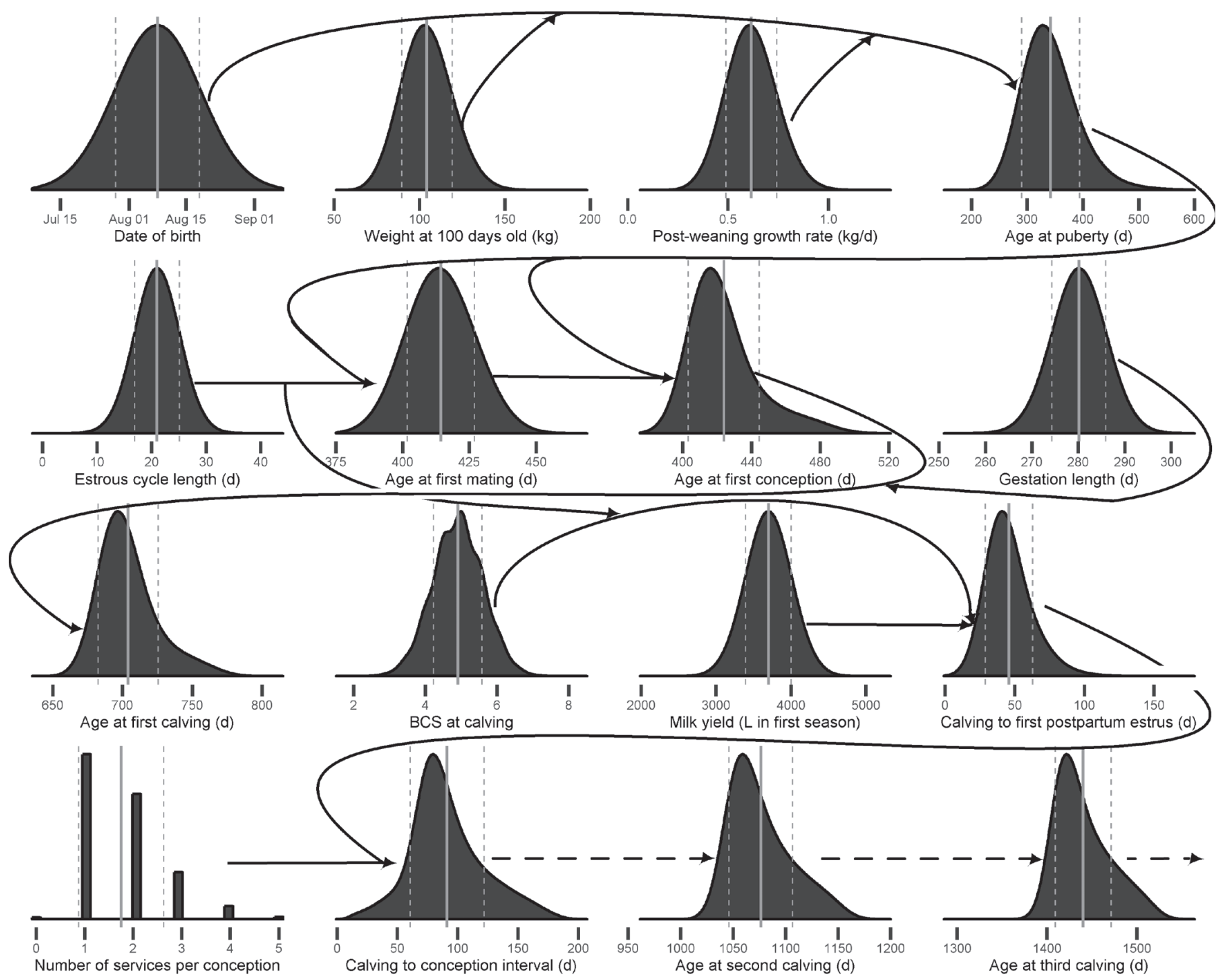

Number of services per conception
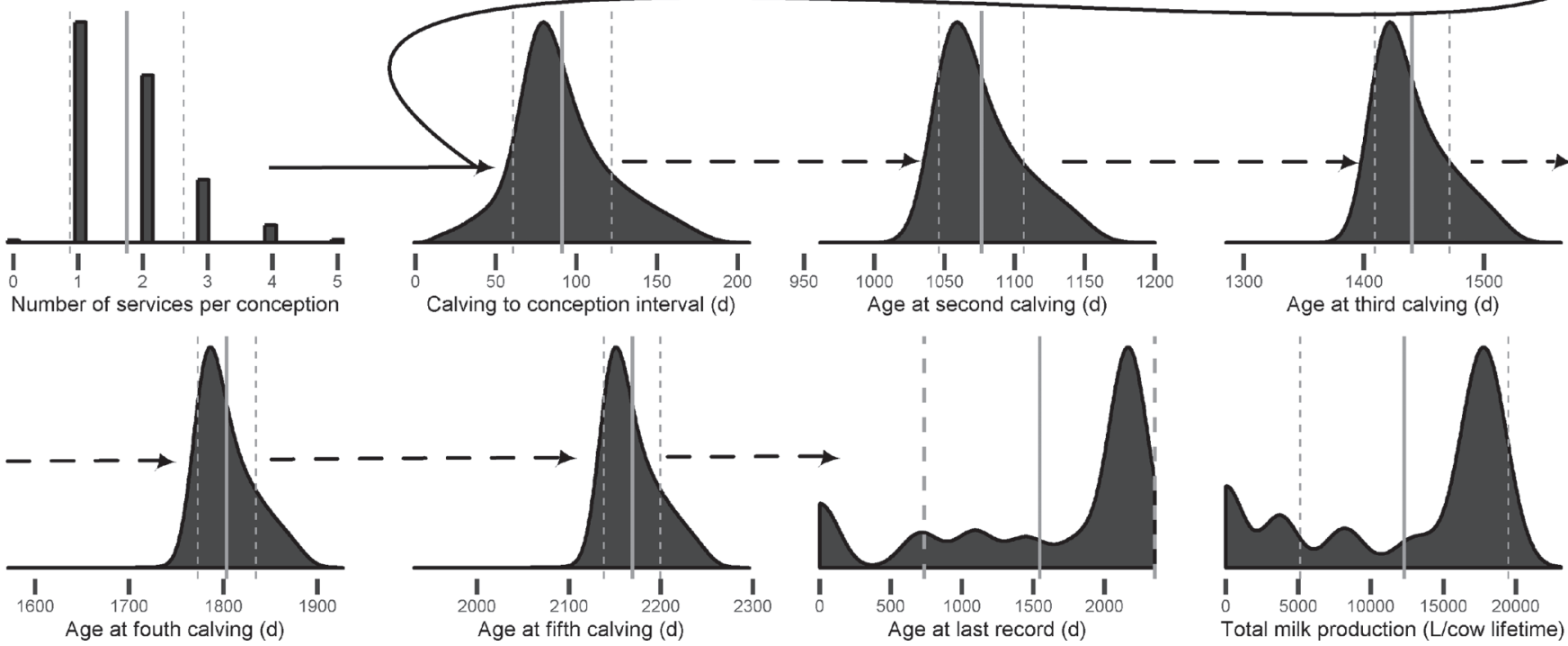

Figure 2. Example of phenotypic distributions in the stochastic model and the interaction of phenotypic driving variables used in the stochastic model. Each simulated animal draws a date of birth at random from a normal distribution, and then development variables (such as weight at $100 \mathrm{~d}$ and growth rate) are determined by correlated genetic traits and environmental and random variation. Variation in any given variable may drive variation in variables further downstream, as indicated with arrows. Mean values (solid line) and 1 SD either side of the mean (broken line) of all animals simulated $(n=20,000,000$ or 100 replicates of 200,000) are shown. 


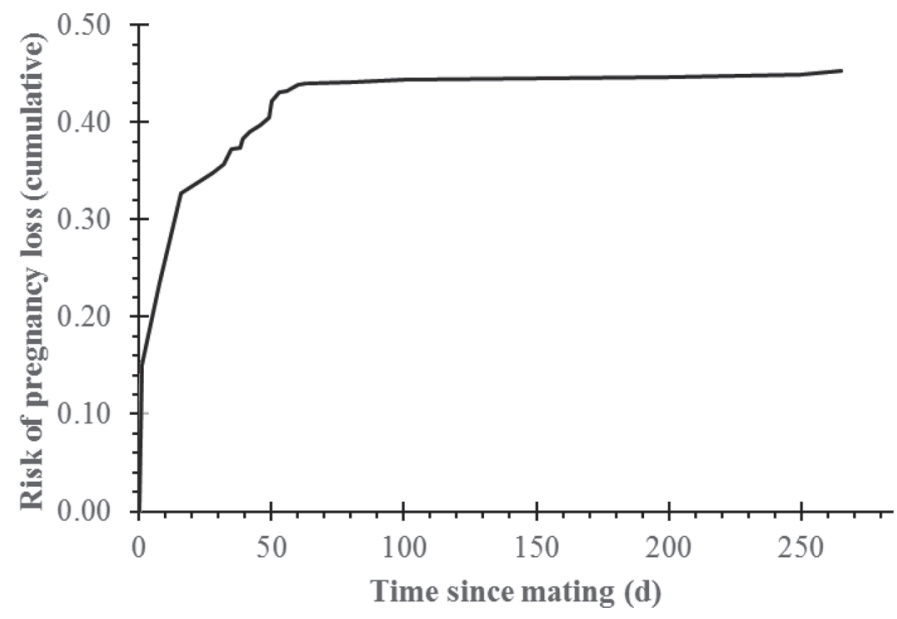

Figure 3. Cumulative risk of embryo or fetal loss over the course of a pregnancy. This curve is used to simulate the risk of pregnancy failure in the stochastic fertility model. Derived from empirical data from New Zealand industry (McDougall et al., 2005) as well as unpublished embryo survival and progesterone data following mating (D. Berg, S. Meier, and C. Burke, unpublished data).

curve (and therefore the risk of pregnancy loss over time) was scaled using the heifer's underlying genetics (TBV values for the number of services to conception), as well as risk factors associated with a twin pregnancy $(+18.5 \%$ risk of loss derived from Sreenan and Diskin, 1986; López-Gatius et al., 2004, 2002) and random environmental effects.

If a pregnancy is lost within the first $16 \mathrm{~d}$ after mating, then the next estrus was set to occur after 1 cycle length plus $2 \mathrm{~d}$ (to simulate the recovery presumed to occur following an early embryo loss) after the mating date. If the pregnancy loss occurred after $16 \mathrm{~d}$ after estrus, then the next estrus occurred 1 cycle length after the pregnancy loss date. Heifers could be mated on their second (and subsequent) estrus events if these occurred before the end of the defined mating season. Heifers that are not pregnant at the end of the mating season are assumed culled and therefore excluded from further simulation.

\section{Milking Cow Module: Simulation of Cow Phenotypes}

Gestation length is simulated using maternal and fetal factors. First calving date was determined from the gestation length and the successful mating date. Calving difficulty is simulated initially as a continuous liability trait using maternal and calf genetics and random environmental variation, and then converted to a binomial incidence. The choice of threshold was determined according to a predefined incidence (Table 2). A low incidence $(0.5 \%$ for normal births and $5 \%$ for difficult births) of maternal mortality was simulated during this time. Total lactation milk yield and BCS for calving and mating periods are also generated.

Performance of lactating cows is simulated as a function of the start date of current mating season, the calving ease in the preceding calving, calving difficulty (difficult calving $=1$, easy calving $=0$ ), calving twins, the date of the preceding calving, the TBV of this season's calf for calving difficulty and gestation length, age factors for milk production (derived from DairyNZ and LIC, 2015), age factors for anestrus treatment efficacy, and calving rates derived from New Zealand data (Xu and Burton, 2003). Age effect factors on mean BCS at calving were derived from New Zealand industry data (Chris Burke, DairyNZ Ltd., Hamilton, New Zealand, personal communication). Briefly, the return to a fertile state after calving is simulated in 3 stages. First, the TBV values for first postpartum ovulation and the effects of BCS loss were used to simulate the first ovulation after calving. The probability of this ovulation being associated with a detectable estrus was simulated using parameters shown in Table 1. Additionally, cows with a mating BCS (1:10 scale) less than 3 had an increased probability $(+20 \%)$ of an ovulation event not associated with estrus activity (i.e., silent ovulation). Second, estrous cycle length in the lactating cow was affected by milk production $(+0.006 \mathrm{~d} / \mathrm{L}$ above average milk production) and the probability of a truncated first cycle, persistent corpus luteum, or delayed ovulation (Fonseca et al., 1983). Third, the estrus to ovulation interval was drawn from a random distribution (mean $=27.2 \mathrm{~h}, \mathrm{SD}=6 \mathrm{~h}$ ). These factors were combined to simulate the first detectable estrus following calving. The model allowed cows to revert to silent ovulations (i.e., ovulations without overt estrus) for the first 3 cycles after calving (see Table 1).

The number of detectable estruses that a cow has before the beginning of the mating season affects the probability of being treated for anestrus. Cows treated for anestrus are assumed to be mated at the start of the mating date and this was associated with a conception rate of $38.6 \%$ (Rhodes et al., 2001).

The likelihood of an ovulation with associated estrus being correctly identified for artificial breeding is based on a human error rate of $6 \%$ and was influenced by the cows TBV for estrus expression (assumed 10\% less likely to be identified for every 1-h decrease in estrus activity), BCS $(-20 \%$ for cows with a BCS $<2.5)$, and the incidence of calving difficulty $(-5 \%)$ or twins $(-5 \%)$ in the preceding calving. A human error rate $(2 \%$ at random) was applied to simulate cows that were submitted for mating when they were not in estrus. This had no effect on a cow's likelihood of being detected in estrus 
at their next estrus event. More information on the above equations can be found in Supplemental Tables S1 and S2 (https://doi.org/10.3168/jds.2017-13355).

Matings, pregnancies, and calvings were modeled to reach the second calving date as described for heifers leading up to their first calving. The process was repeated for a total of 5 parities. The simulation was ceased at this point to limit computational demands required to analyze the results. Each replicate of the stochastic fertility model was used to simulate the records from 200,000 cows, which were generated from random matings of 200 sires and 200,000 dams (all of which were assumed to be unrelated). When replicated 100 times, the model generated data for $20,000,000$ daughters.

\section{Genetic Analysis of Simulated Records}

Simulated cow records from the stochastic fertility model are used to assign industry equivalent phenotypes to each cow. These simulated records are then analyzed to investigate genetic variance and generate EBV. We used a univariate sire model to calculate sire EBV using the "lme4" package in R (Bates et al., 2015), as follows:

$$
y=\mu+\operatorname{sire}+e
$$

where $y$ is a record simulated by the model (e.g., age at first estrus), $\mu$ is the overall mean of the trait (fixed effect), sire is the random genetic effect of the sire of the cow (which is used to generate EBV), and $e$ is the random residual. For each replicate of a trait, the sire genetic variance $\left(V_{s}\right)$ and residual variance $\left(V_{e}\right)$ were estimated and used to calculate the heritability of the trait, as follows:

$$
\mathrm{h}^{2}=\frac{4 V_{s}}{V_{s}+V_{e}}
$$

Correlations between EBV were used as approximate genetic correlations. With 1,000 daughters simulated per sire, EBV are a very close approximate of the TBV, and as such correlations among sire EBV are a very good prediction of the corresponding genetic correlations.

\section{Genetic Analysis of Lifetime Reproductive Success}

The number of times each animal calved within the first $42 \mathrm{~d}$ of the annual calving season was considered as the LRS value. The maximum LRS was 5, which represented cows that remained in the herd for 5 calvings (the entirety of the simulation) with all calvings occurring within the first $42 \mathrm{~d}$ of each calving season. The minimum LRS was 0 , which represented cows that calved consistently late or were culled for poor fertility at an early age.

Sire EBV for LRS were calculated from daughter records. Predictor traits for LRS were identified using linear regression of the sire's predictor trait EBV and the LRS EBV. Predictors with the highest adjusted $\mathrm{R}^{2}$ were included via stepwise regression to find the most predictive model of sire LRS.

For each simulation replicate, sires were ranked on LRS EBV and daughters from the highest sires $(\mathrm{n}=$ $100)$ and lowest sires $(n=100)$ were selected for the daughters from high LRS sires (HiFERT; $\mathrm{n}=99,995$ ) and LoFERT ( $\mathrm{n}=99,635)$ divergent lines. Because matings are randomly assigned, every sire does not have exactly 1,000 daughters. The TBV of the HiFERT and LoFERT daughters were compared with investigate the underlying genetics of LRS. Student's $t$-test was used to confirm significant difference between the lines, with a cut-off of $P>0.05$ used to define significance.

\section{RESULTS AND DISCUSSION}

\section{Summary of Simulation Outputs}

Our literature review found that some components of female fertility, such as age at puberty, gestation length, estrous cycle length, and the interval between calving and first postpartum ovulation are moderately to highly heritable (Table 2). In contrast, traits based on empirical calving and mating data have low heritability estimates (Veerkamp and Beerda, 2007). Using mathematical simulation, we have replicated the input of high heritability components into a low heritability trait. The genetic variance and covariance estimates for the 14 component traits of fertility in the simulated records are broadly consistent with the inputs used to parameterize the model (Table 3). Some stronger relationships have been diluted, possibly due to the addition of many unknown trait correlations where the genetic correlations have been included as zero in the inputs. It is also possible that, for some traits, additional phenotypic variation is included due to management or environmental factors (such as hormonal treatments or twinning), or both, that we simulate but then do not include in the regression when we estimate genetic parameters.

There are many ways to assess fertility, and a variety of these have been compared using the simulated data. As we expected, traits derived from outputs of the model, such as calving interval $\left(h^{2}=0.018\right)$, number 
of services per conception $\left(\mathrm{h}^{2}=0.024\right)$, age at first calving $\left(\mathrm{h}^{2}=0.051\right)$, first insemination success rate $\left(\mathrm{h}^{2}\right.$ $=0.031$ ), calving rate in the first $42 \mathrm{~d}$ of calving season $\left(\mathrm{h}^{2}=0.026\right)$, and submitted for mating in the first $21 \mathrm{~d}$ of the mating season $\left(\mathrm{h}^{2}=0.041\right)$, had low heritability estimates.

Our results confirm that fertility traits have a low heritability, not because of a lack of genetic variation in the component traits driving mating and calving outcomes, but because the amount of environmental variation in fertility is much larger by comparison even with perfectly accurate herd recording. In industry data where incomplete or erroneous data are present, heritability estimates of fertility may be even lower.

In the simulation results, less than $40 \%$ of cows avoided fertility-related culling until the fourth lactation. This is broadly consistent with longevity of dairy cows worldwide (Hare et al., 2006; Heins et al., 2012; DairyNZ and LIC, 2015). We found that with increasing parity, the average calving date became earlier, calving interval was reduced, the proportion of anestrus and anovulatory animals at the start of mating reduced, and the mating success rate and early calving rate improved (Table 4). This is consistent with the literature used to parameterize the model and with the poor rebreeding success rate of late-calving cows, which have a shorter recovery period from calving to the next mating season (Xu and Burton, 2003).

In contrast to year-round mating systems, early calving seasonal cows have a longer interval from calving to mating (i.e., mating is withheld until the fixed point in time at which the mating season commences).
Consequently, calving to first insemination interval and calving to conception interval increased in later parities (Table 4).

\section{Early Predictors of Lifetime Reproductive Success}

When selecting for high fertility sires, those that have daughters that are still reproducing well in later parities are the most desirable. However, it is impractical to wait until a sire has daughters in their fifth lactation to identify high fertility sires for widespread industry use. Therefore, we have investigated the relationship between traits expressed earlier in life and LRS. In the simulated results, LRS was defined by aggregating the number of early calvings over the cow's lifetime to give a LRS trait $\left(\mathrm{h}^{2}=0.09, \mu=2.4\right)$. We selected this definition because, in the seasonal-pastoral system, having a high proportion of cows calving in the first $6 \mathrm{wk}$ is desirable for pasture management and LRS is a direct measurement of a cow's ability to achieve this goal consistently over her lifetime. The genetic parameters of potential predictors for LRS are shown in Table 5 . These are broadly consistent with estimates from industry data from seasonal systems, although heritability estimates were generally lower in the industry data (Berry et al., 2003a; Bowley et al., 2015; Stachowicz et al., 2015a; Amer et al., 2016). On average, heritability estimates were +0.016 higher in the perfectly recorded simulated data compared with reported industry data. This difference likely reflects additional error or noise variation due to erroneous or incomplete producer records that we have not simulated.

Table 4. Phenotype means (and SD within replicates) across parities for cohort of 200,000 simulated cows

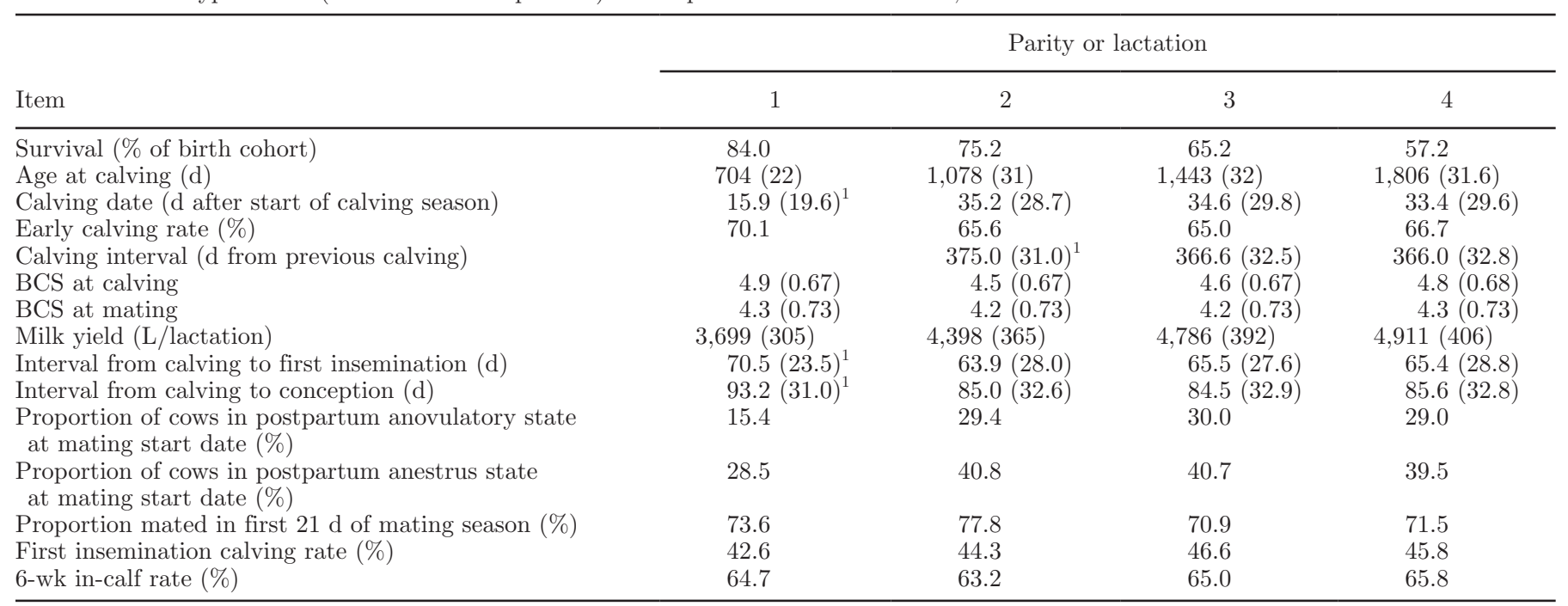

${ }^{1}$ Early calving rate is defined as cows calving within the first $21 \mathrm{~d}$ of the calving season for parity 1 and the first $42 \mathrm{~d}$ for later parities. As standard practice, first mating heifers were mated earlier than cows already in the milking herd, which led to an earlier first calving season day and a longer first calving interval. 
Table 5. Potential predictor traits of lifetime reproductive success (listed in approximate order of recording) with simulated heritability $\left(\mathrm{h}^{2}\right)$ and genetic correlation with lifetime reproductive success (LRS; Rg) ${ }^{1}$

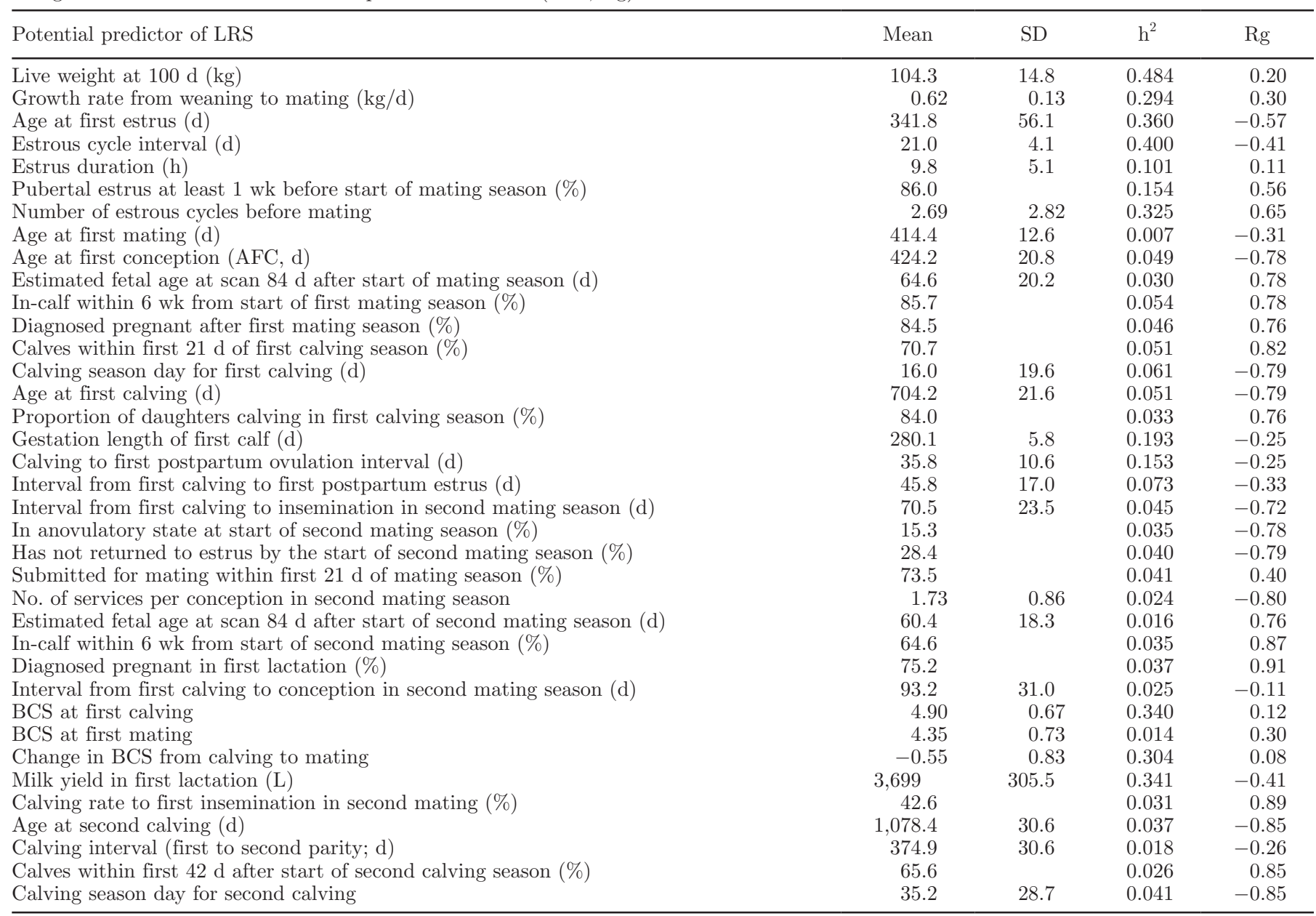

${ }^{1}$ Simulated mean and SD (between animals) also shown.

Fertility traits in the second parity were generally better predictors of LRS than first parity traits. One explanation is selection bias whereby cows that calved late or did not calve at all in the first parity would not be early calving cows in the second parity and are unlikely to be early calving cows in subsequent parities. In addition, some variables with genetic influences (such as postpartum anestrus interval, milk production, and BCS influence on estrus detection success) affect lactating cows, but do not influence heifers in the first mating season. Thus, first-parity fertility is not fully representative of subsequent parities because heifers are managed differently from, and are not subject to the metabolic stresses of, lactating dairy cows.

Pregnancy diagnosis rate (the proportion of daughters diagnosed pregnant when tested $60 \mathrm{~d}$ after the end of the mating season) in the second mating season (PD_1) was the strongest predictor of sire LRS, accounting for $81 \%$ of the overall genetic variation in LRS.
This was closely followed by a proportion of daughters pregnant within the first 6 wk of the same mating season $\left(\right.$ ICR6_1; $\left.R^{2}=0.79\right)$. Although both PD_1 and ICR6_1 could be considered a function of conception rate, there was additive additional predictive value when both traits were used as predictors in the model derived data (Table 6). The strongest combination of predictors, found by stepwise regression, was PD_1 and calving date in the second parity, which explained an estimated $96.6 \%$ of genetic variation in LRS (Table $6)$. The LRS prediction was further improved $\left(\mathrm{R}^{2}=\right.$ 0.974 ) by the addition of ICR6_1, early calving rate in the first parity, and daughter puberty rate in the week preceding the first mating season (Table 6). This is consistent with reports that first parity fertility traits and second parity calving date (as a continuous calving season day trait) are strong predictors of ongoing cow reproductive success in a seasonal system (Stachowicz et al., 2015a,b). 
Table 6. Marginal benefit of predictors for lifetime reproductive success (LRS) ${ }^{1}$

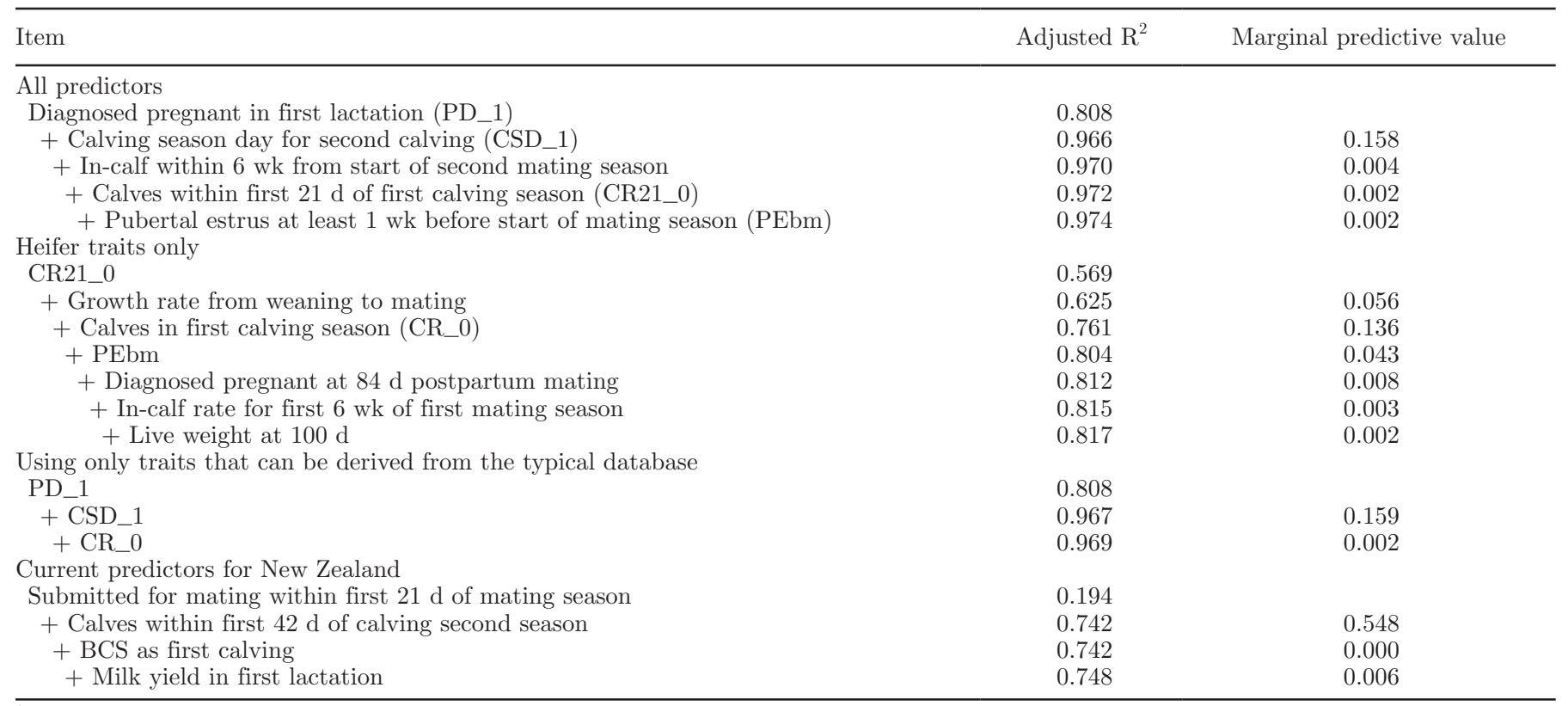

${ }^{1}$ Iterative analysis of best models for prediction of LRS EBV using EBV from all predictors listed in Table 5, or restricting analysis to predictors that are recorded within the first 2 yr (heifer traits) or predictors that can be taken from data in the current recording system (database traits). For each iteration, the model with the highest $\mathrm{R}^{2}$ was recorded. Iterations ceased when the marginal predictive value (difference between the $\mathrm{R}^{2}$ of the new model and the previous model) of the next model fell below 0.002 except for the final predictive model in which the traits were specified by using current predictors.

It is, therefore, possible to accurately predict a sire LRS EBV using a combination of first and second parity records (when the daughters are around $4 \mathrm{yr}$ old). However, it would be beneficial to evaluate genetic merit for fertility of sires earlier than the second parity of their daughters; therefore, we also analyzed prediction models that were restricted to traits occurring before the first daughter lactation. The best model consisted of 7 early traits, including heifer growth traits, and predicted $81.7 \%$ of sire variation in LRS EBV (Table 6). Although the adjusted $\mathrm{R}^{2}$ of this model is lower $(-0.157)$ than a model containing second parity records, predictions would be available 1 yr earlier.

Both predictive models for which results are described thus far include some traits that may be difficult to record in a large-scale progeny test. A third predictive model was therefore investigated that included traits that can be derived from routinely collected calving and mating records. The best simple model included 3 traits: calving rate of daughters in the first and second parities and the calving season day for the second parity. The predictive power of this model was 0.005 below the best model (using all the traits), indicating that a good prediction of sire LRS can be made with relatively inexpensive recording methods. In comparison, a fourth predictive model that was created using the current predictors used in the New Zealand genetic evaluation for fertility (Harris et al., 2006) had a much lower predictive value than the most predictive model (Table 6). This suggests that some simple adjustments could be made to further improve genetic evaluation for fertility in New Zealand. However, it should be noted that the simulated results come from animals modeled to be under the same general environment (which is based on the average New Zealand system), whereas current New Zealand predictor traits may have greater marginal predictive value when comparing herds with different management types (e.g., different emphasis on estrus detection, feeding or milk production) and much of the information about the management of each herd (e.g., the start and the duration of the mating season, and so on) is not known. Although an antagonistic relationship between milk yield and fertility was included in the model (both in the genetic correlations and in the phenotypic drivers of estrus expression), milk yield was not a strong predictor of LRS. This is consistent with results derived from field data (Amer et al., 2016).

\section{Effect of High and Low Fertility Sires}

Our results indicate that a sire's LRS breeding value can be predicted using traits expressed relatively early in the lifetime of his daughters. This modeling approach was also applied to identify candidate traits, which could be the principal underlying causes of genetic variation in fertility traits, which determine LRS in a seasonal 
calving system. The wide spread use (1,000 daughters/ sire) of sires with high $(\mu=+0.70)$ and low $(\mu=-0.73)$ breeding values for LRS was simulated. As could be expected from the sire breeding values, HiFERT had a higher early calving rate with 1.48 more calvings within the first $42 \mathrm{~d}$ of the calving season per cow lifetime ( $\mu$ $=3.12$ ) than LoFERT (1.64). The distribution of the underlying genetic traits of the simulation model are illustrated in Figure 4. Of the 14 driving genetic traits used in the simulation, 12 were significantly divergent
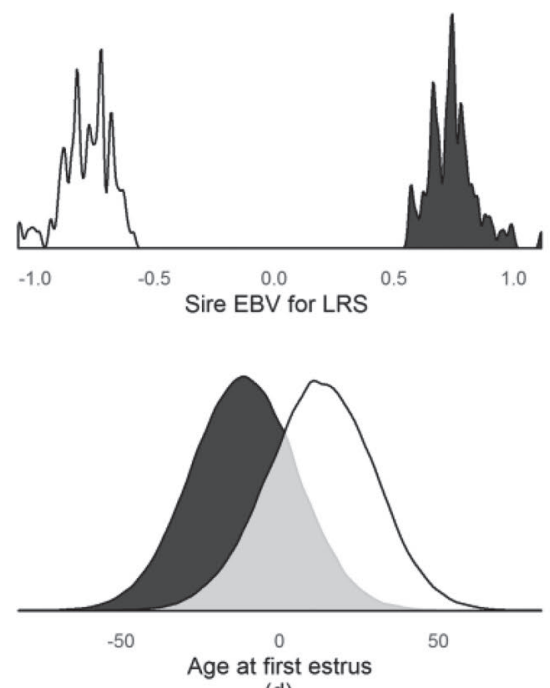

(d)
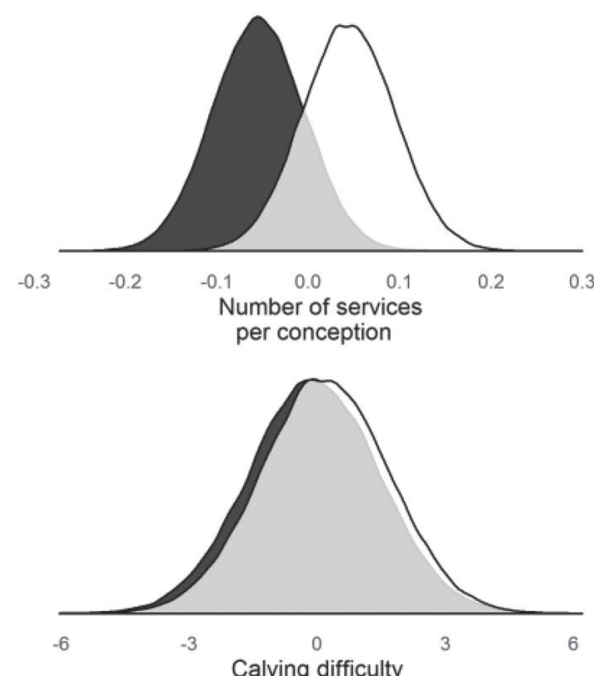

$(\%)$

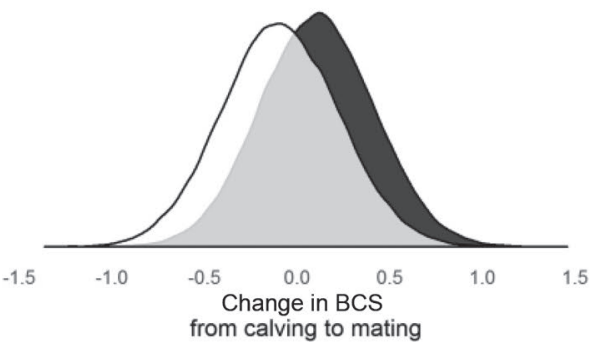

Figure 4. The fundamental genetic drivers of lifetime reproductive success (LRS). Distribution of the underlying genetics in simulated daughters from high LRS sire (black) and low LRS sire (white) fertility lines. Bulls with the highest $(\mathrm{n}=100)$ and lowest ( $\mathrm{n}=100)$ EBV for daughter LRS were identified to simulate divergent lines. Density plots of the true breeding values of the daughters (1,000 daughters per sire from random matings) for the 14 underlying genetic traits of the stochastic model are shown. In a nonselected population, the mean of the breeding values would be zero (marked on $\mathrm{x}$-axis of each plot). All drivers were significantly different $(P<0.05)$ except calving difficulty.

Journal of Dairy Science Vol. 101 No. 4, 2018 
(Student's $t$-test, all $P$-values less than 0.0001), suggesting that female reproductive success is a result of a complex interaction between driving variables. The key TBV differences between these simulated sire lines included conception rate (number of services per conception), estrous cycle length, age at first estrus, rate of heifer growth relative to mature size, and milk yield.

True breeding values for calving difficulty were not significantly different between the HiFERT and LoFERT daughters even though calving difficulty had direct effects on cow survival $(5 \%$ greater mortality at calving), successful detection of estrus at mating (5\% less), and embryo survival ( $5 \%$ less). This is probably because calving difficulty was simulated as a low heritability and low incidence trait, which is consistent with the seasonal-pastoral systems of New Zealand. Body condition score at calving was significantly different $(P$ $<0.001$ ) between the lines, but the difference was small (0.036 units higher in the HiFERT group). This suggests that either BCS at calving is not a strong driver of LRS or that this trait cannot diverge because it is constrained by competing trait correlations. The latter is more likely because calving BCS has strong unfavorable genetic correlations with milk yield and with change in BCS from calving to mating and a strong favorable genetic correlation with calving to first postpartum ovulation interval (Table 3). Milk yield and mature live weight TBV were low in HiFERT daughters, indicating that LRS was more favorable in genetically small, lower yielding cows, which is consistent with the antagonistic genetic correlations of fertility traits with milk yield and with live weight used as inputs in the model (Table 3). However, a selection line experiment undertaken in pastoral cows in Ireland found that cows with high genetic merit for fertility had higher milk production (Cummins et al., 2012a,b). Pryce et al. (2014) showed that field data estimates of the antagonistic genetic cor- relation between milk production and industry recorded fertility traits becomes stronger as the population phenotypic mean milk production increases. Recent field data estimates of this genetic correlation in New Zealand have also indicated a relatively weak antagonistic correlation (Amer et al., 2016).

The HiFERT daughters also had higher TBV for weaning weight (live weight at $100 \mathrm{~d}$ ) and faster growth rates from weaning to mating suggesting that they grew faster, but had a lower mature live weight, than LoFERT animals. In the simulated phenotypic records, HiFERT daughters displayed first pubertal estrus 34.1 d earlier (Table 7), which is a larger difference than would be expected from the breeding values for age at first estrus (HiFERT $-9.59 \mathrm{~d}$, LoFERT +7.13 d). This was driven by a rapid weight gain (per unit of mature size) in HiFERT animals (Table 8), which is a driving variable of pubertal onset in the simulation model. Earlier first estrus lead to an earlier first conception in the HiFERT animals ( $8.4 \mathrm{~d}$ younger). The age difference increased further at first calving (10.4 d) due to a $1 \mathrm{~d}$ shorter gestation length and lower pregnancy loss in the HiFERT cows. For subsequent parities, HiFERT daughters calved around $15 \mathrm{~d}$ earlier than their LoFERT contemporaries (Table 7). By the fifth parity, $67.5 \%$ of the HiFERT daughters remained in the analysis compared with $37.5 \%$ of the LoFERT daughters. These results suggest that, although LRS is a low heritability trait, many underlying traits have genetic variation subject to selection and effective selection for fertility traits (or inadvertently using low fertility sires to detrimental effect) can substantially alter a wide range of traits. For almost all traits simulated in this model, HiFERT daughters showed favorable change. In contrast, twinning rate $(+1.4 \%)$ and milk yield $(-213$ $\mathrm{L} /$ lactation or a $5.6 \%$ reduction) were unfavorably affected in HiFERT cows when compared with LoFERT

Table 7. Survival rates and ages at fertility milestones in simulated daughters of sires with high (HiFERT, n $=100,352$ ) and low (LoFERT, $\mathrm{n}=99,706)$ genetic merit for lifetime reproductive success

\begin{tabular}{lccccc}
\hline & \multicolumn{2}{c}{ HiFERT } & & \multicolumn{2}{c}{ LoFERT } \\
\cline { 2 - 3 } \cline { 5 - 6 } Time point & $\begin{array}{c}\text { Survival } \\
(\%)\end{array}$ & Mean (d) $\pm \mathrm{SE}$ & & $\begin{array}{c}\text { Survival } \\
(\%)\end{array}$ & Mean $(\mathrm{d}) \pm \mathrm{SE}$ \\
\hline Birthday (Julian day) & 100 & $219.1 \pm 0.03$ & & 100 & $219.0 \pm 0.03$ \\
Age at first estrus & 99.9 & $317.1 \pm 0.16$ & & 99.2 & $361.6 \pm 0.19$ \\
Age at first mating & 99.9 & $413.8 \pm 0.04$ & & 99.4 & $414.9 \pm 0.04$ \\
Age at first conception & 90.3 & $419.9 \pm 0.06$ & & 70.5 & $430.8 \pm 0.09$ \\
Age at first calving & 90.3 & $699.0 \pm 0.06$ & & 70.5 & $711.8 \pm 0.09$ \\
Age at second calving & 84.5 & $1,071.5 \pm 0.10$ & & 58.3 & $1,085.8 \pm 0.13$ \\
Age at third calving & 77.1 & $1,435.2 \pm 0.11$ & & 47.5 & $1,450.1 \pm 0.15$ \\
Age at fourth calving & 70.9 & $1,798.9 \pm 0.11$ & & 39.4 & $1,813.6 \pm 0.17$ \\
Age at fifth calving & 64.8 & $2,164.0 \pm 0.12$ & & 32.5 & $2,178.4 \pm 0.18$ \\
\hline
\end{tabular}


Table 8. Simulated phenotypes of daughters of sires with high (HiFERT) and low (LoFERT) genetic merit for lifetime reproductive success $($ mean \pm SEM $)$

\begin{tabular}{|c|c|c|c|}
\hline Time & Trait & HiFERT & LoFERT \\
\hline & Live weight at $100 \mathrm{~d}(\mathrm{~kg})$ & $106.6 \pm 0.1$ & $98.9 \pm 0.1$ \\
\hline First $\mathrm{m}$ & Estrous cycle length (d) & $19.7 \pm 0.01$ & $22.4 \pm 0.01$ \\
\hline & Estrus duration $(\mathrm{h})$ & $10.0 \pm 0.02$ & $9.6 \pm 0.02$ \\
\hline & Number of estruses before mating & $4.3 \pm 0.01$ & $0.85 \pm 0.01$ \\
\hline & Early pregnancy rate (within first $21 \mathrm{~d} ; \%$ ) & $81.4 \pm 0.1$ & $56.6 \pm 0.1$ \\
\hline \multicolumn{4}{|c|}{ First calving season } \\
\hline & Calving date (d since start of calving season) & $10.9 \pm 0.1$ & $23.2 \pm 0.1$ \\
\hline & Calving rate $(\%)$ & $90.3 \pm 0.1$ & $70.1 \pm 0.1$ \\
\hline & Twinning rate $(\%)$ & $3.7 \pm 0.1$ & $2.3 \pm 0.1$ \\
\hline & Calving difficulty $(\%)$ & $8.0 \pm 0.1$ & $8.3 \pm 0.1$ \\
\hline & Gestation length (d) & $279.2 \pm 0.02$ & $281.0 \pm 0.02$ \\
\hline & In postpartum anovulatory state at start of mating $(\%)$ & $7.8 \pm 0.1$ & $27.4 \pm 0.2$ \\
\hline & Calving to first postpartum estrus interval (d) & $43.4 \pm 0.5$ & $48.1 \pm 0.7$ \\
\hline & In postpartum anestrus state at start of mating (\%) & $18.0 \pm 0.1$ & $41.8 \pm 0.2$ \\
\hline & Calving to first insemination interval (d) & $75.1 \pm 0.1$ & $63.5 \pm 0.1$ \\
\hline & Early mating rate (within first $21 \mathrm{~d}, \%$ ) & $77.3 \pm 0.1$ & $70.3 \pm 0.2$ \\
\hline & First mating or insemination calving rate (\%) & $54.5 \pm 0.2$ & $30.4 \pm 0.2$ \\
\hline & Early pregnancy rate (within first $42 \mathrm{~d}, \%$ ) & $74.6 \pm 0.1$ & $54.4 \pm 0.2$ \\
\hline & Calving to conception interval (d) & $92.0 \pm 0.1$ & $92.6 \pm 0.1$ \\
\hline & No. of services per conception & $1.6 \pm 0.003$ & $1.9 \pm 0.004$ \\
\hline \multicolumn{4}{|c|}{ Second calving season } \\
\hline & $\begin{array}{l}\text { Early calving rate (within first } 42 \mathrm{~d}, \%) \\
\text { Calving date (d since start of calving season) }\end{array}$ & $\begin{array}{l}75.0 \pm 0.2 \\
28.4 \pm 0.09\end{array}$ & $\begin{array}{l}55.5 \pm 0.2 \\
42.3 \pm 0.13\end{array}$ \\
\hline & Calving interval $(\mathrm{d})$ & $372.8 \pm 0.1$ & $375.3 \pm 0.14$ \\
\hline
\end{tabular}

cows. However, HiFERT cows would be expected to have an extra 14 DIM per lactation due to their earlier calving date, which may mitigate their lower genetic potential for milk production (DIM effects on milk yield were not simulated). In a balanced selection index, selection pressure would also be placed on milk yield, which would mitigate any detrimental effects of selecting for fertility. Here, even in the simulated singletrait selection lines the HiFERT cows produced 33\% more milk over their lifetime (HiFERT $=13,612 \mathrm{~L} /$ cow, LoFERT $=10,228 \mathrm{~L} /$ cow) because of their longer productive life $(+1.3 \mathrm{yr})$.

\section{CONCLUSIONS}

From these simulations, we conclude that increasing genetic merit for LRS in dairy cows leads to greater survival and lifetime milk production and that good predictions of LRS can be made using predictor traits that are easily accessible (e.g., pregnancy success and calving season day) from industry records.

\section{ACKNOWLEDGMENTS}

This work was funded by the Ministry of Business, Innovation and Employment (Wellington, New Zealand) and by New Zealand dairy farmers through DairyNZ Inc. (Hamilton, New Zealand). The authors gratefully acknowledge Olivier Martin and Fabienne Blanc (AgroParisTech, Paris, France) for discussions on modelling reproductive physiology.

\section{REFERENCES}

Amer, P. R., K. Stachowicz, G. M. Jenkins, and S. Meier. 2016. Short communication: Estimates of genetic parameters for dairy fertility in New Zealand. J. Dairy Sci. 99:8227-8230.

Båge, R., H. Gustafsson, B. Larsson, M. Forsberg, and H. RodríguezMartínez. 2002. Repeat breeding in dairy heifers: Follicular dynamics and estrous cycle characteristics in relation to sexual hormone patterns. Theriogenology 57:2257-2269. https://doi.org/10 .1016/S0093-691X(02)00840-3.

Bamber, R. L., G. E. Shook, M. C. Wiltbank, J. E. P. Santos, and P. M. Fricke. 2009. Genetic parameters for anovulation and pregnancy loss in dairy cattle. J. Dairy Sci. 92:5739-5753. https://doi .org/10.3168/jds.2009-2226. 
Banos, G., and M. P. Coffey. 2010. Genetic association between body energy measured throughout lactation and fertility in dairy cattle. Animal 4:189-199. https://doi.org/10.1017/S1751731109991182.

Bates, D., M. Mächler, B. Bolker, and S. Walker. 2015. Fitting linear mixed-effects models using lme4. J. Stat. Softw. 67: https://doi .org/10.18637/jss.v067.i01.

Beaver, B. V. G. 2009. Canine Behavior: Insights and Answers. 2nd ed. Elsevier Health Sciences.

Berry, D. P., F. Buckley, P. Dillon, R. D. Evans, M. Rath, and R. F. Veerkamp. 2002. Genetic parameters for level and change of body condition score and body weight in dairy cows. J. Dairy Sci 85:2030-2039. https://doi.org/10.3168/jds.S0022-0302(02)74280 $-\mathrm{X}$.

Berry, D. P., F. Buckley, P. Dillon, R. D. Evans, M. Rath, and R. F. Veerkamp. 2003a. Genetic relationships among body condition score, body weight, milk yield, and fertility in dairy cows. J. Dairy Sci. 86:2193-2204. https://doi.org/10.3168/jds.S0022 -0302(03)73809-0.

Berry, D. P., F. Buckley, P. Dillon, R. D. Evans, M. Rath, and R. F. Veerkamp. 2003b. Genetic parameters for body condition score, body weight, milk yield, and fertility estimated using random regression models. J. Dairy Sci. 86:3704-3717. https://doi.org/10 .3168/jds.S0022-0302(03)73976-9.

Bowley, F. E., R. E. Green, P. R. Amer, and S. Meier. 2015. Novel approaches to genetic analysis of fertility traits in New Zealand dairy cattle. J. Dairy Sci. 98:2005-2012. https://doi.org/10.3168/ jds.2014-8266.

Buttchereit, N., E. Stamer, W. Junge, and G. Thaller. 2011. Short communication: genetic relationships among daily energy balance, feed intake, body condition score, and fat to protein ratio of milk in dairy cows. J. Dairy Sci. 94:1586-1591. https://doi.org/10 $.3168 /$ jds.2010-3396.

Cassandro, M. 2014. Genetic aspects of fertility traits in dairy cattleReview. Acta Agrar. Kaposváriensis 18:11-23.

Coffey, M. P., J. Hickey, and S. Brotherstone. 2006. Genetic aspects of growth of Holstein-Friesian dairy cows from birth to maturity. J. Dairy Sci. 89:322-329. https://doi.org/10.3168/jds.S0022 -0302(06)72097-5.

Cummins, S. B., P. Lonergan, A. C. O. Evans, D. P. Berry, R. D. Evans, and S. T. Butler. 2012a. Genetic merit for fertility traits in Holstein cows: I. Production characteristics and reproductive efficiency in a pasture-based system. J. Dairy Sci. 95:1310-1322. https://doi.org/10.3168/jds.2011-4742.

Cummins, S. B., P. Lonergan, A. C. O. Evans, and S. T. Butler. 2012b. Genetic merit for fertility traits in Holstein cows: II. Ovarian follicular and corpus luteum dynamics, reproductive hormones, and estrus behavior. J. Dairy Sci. 95:3698-3710. https://doi.org/ 10.3168/jds.2011-4976.

DairyNZ and LIC. 2015. New Zealand Dairy Statistics 2014/15. Accessed May 31, 2015. http://www.dairynz.co.nz/publications/ dairy-industry/new-zealand-dairy-statistics-2014-15/.

Darwash, A. O., G. E. Lamming, and J. A. Woolliams. 1997. Estimation of genetic variation in the interval from calving to postpartum ovulation of dairy cows. J. Dairy Sci. 80:1227-1234. https://doi .org/10.3168/jds.S0022-0302(97)76051-X.

De Vries, A. 2006. Economic value of pregnancy in dairy cattle. J. Dairy Sci. 89:3876-3885. https://doi.org/10.3168/jds.S0022 $-0302(06) 72430-4$.

Dechow, C. D., G. W. Rogers, and J. S. Clay. 2002. Heritability and correlations among body condition score loss, body condition score, production and reproductive performance. J. Dairy Sci. 85:30623070. https://doi.org/10.3168/jds.S0022-0302(02)74393-2.

Dowle, M., A. Srinivasan, T. Short, S.L. with contributions from R. Saporta, and E. Antonyan. 2015. Data.table: Extension of data. frame. R Package version 1.9.6.

Dransfield, M. B. G., R. L. Nebel, R. E. Pearson, and L. D. Warnick. 1998. Timing of insemination for dairy cows identified in estrus by a radiotelemetric estrus detection system. J. Dairy Sci. 81:18741882. https://doi.org/10.3168/jds.S0022-0302(98)75758-3.

Fonseca, F. A., J. H. Britt, B. T. McDaniel, J. C. Wilk, and A. H. Rakes. 1983. Reproductive traits of Holsteins and Jerseys. Effects of age, milk yield, and clinical abnormalities on involution of cervix and uterus, ovulation, estrous cycles, detection of estrus, conception rate, and days open. J. Dairy Sci. 66:1128-1147. https://doi .org/10.3168/jds.S0022-0302(83)81910-9.

González-Recio, O., M. A. Pérez-Cabal, and R. Alenda. 2004. Economic value of female fertility and its relationship with profit in Spanish dairy cattle. J. Dairy Sci. 87:3053-3061. https://doi.org/ 10.3168/jds.S0022-0302(04)73438-4.

Grosshans, T., Z. Z. Xu, L. J. Burton, D. L. Johnson, and K. L. Macmillan. 1997. Performance and genetic parameters for fertility of seasonal dairy cows in New Zealand. Livest. Prod. Sci. 51:41-51. https://doi.org/10.1016/S0301-6226(97)00104-8.

Hahn, J. 1969. Inheritance of fertility in cattle inseminated artificially. J. Dairy Sci. 52:240-244. https://doi.org/10.3168/jds.S0022 -0302(69)86536-7.

Hare, E., H. D. Norman, and J. R. Wright. 2006. Survival rates and productive herd life of dairy cattle in the United States. J. Dairy Sci. 89:3713-3720. https://doi.org/10.3168/jds.S0022 $-0302(06) 72412-2$

Harris, B. L., J. E. Pryce, Z. Z. Xu, and W. A. Montgomerie. 2006. Development of new fertility breeding values in the dairy industry. Proc. N.Z. Soc. Anim. Prod. 66:107-112.

Heins, B. J., L. B. Hansen, and A. De Vries. 2012. Survival, lifetime production, and profitability of Normande $\times$ Holstein, Montbéliarde $\times$ Holstein, and Scandinavian Red $\times$ Holstein crossbreds versus pure Holsteins. J. Dairy Sci. 95:1011-1021. https://doi.org/ $10.3168 /$ jds.2011-4525.

Heuer, C., A. Healy, and C. Zerbini. 2007. Economic effects of exposure to bovine viral diarrhea virus on dairy herds in New Zealand. J. Dairy Sci. 90:5428-5438. https://doi.org/10.3168/jds.2007-0258.

Kaps, M., W. O. Herring, and W. R. Lamberson. 2000. Genetic and environmental parameters for traits derived from the Brody growth curve and their relationships with weaning weight in Angus cattle. J. Anim. Sci. 78:1436-1442.

Knauer, M. T., J. P. Cassady, D. W. Newcom, and M. T. See. 2010. Estimates of variance components for genetic correlations among swine estrus traits. J. Anim. Sci. 88:2913-2919. https://doi.org/10 $.2527 /$ jas.2009-2639

Koeck, A., F. Miglior, J. Jamrozik, D. F. Kelton, and F. S. Schenkel. 2014. Genetic relationships of fertility disorders with reproductive traits in Canadian Holsteins. DCBGC Fertil. Rep. Proceedings of the 10th World Congress on Genetics Applied to Livestock Production, August 17-22, 2014.

Koenen, E. P. C., R. F. Veerkamp, P. Dobbelaar, and G. De Jong. 2001. Genetic analysis of body condition score of lactating Dutch Holstein and Red-and-White heifers. J. Dairy Sci. 84:1265-1270. https://doi.org/10.3168/jds.S0022-0302(01)74588-2.

Lamming, G. E., and A. O. Darwash. 1998. The use of milk progesterone profiles to characterise components of subfertility in milked dairy cows. Anim. Reprod. Sci. 52:175-190.

Lee, A. J., D. A. Boichard, A. J. McAllister, C. Y. Lin, K. Nadarajah, T. R. Batra, G. L. Roy, and J. A. Vesely. 1992. Genetics of growth, feed intake, and milk yield in Holstein cattle. J. Dairy Sci. 75:3145-3154. https://doi.org/10.3168/jds.S0022-0302(92)78078 $-3$.

Leydold, J., and W. Hörmann. 2015. Runuran: R Interface to the UNU.RAN random variate generators. https://cran.r-project.org/ web/packages/Runuran/index.html.

Lopez, H., L. D. Satter, and M. C. Wiltbank. 2004. Relationship between level of milk production and estrous behavior of lactating dairy cows. Anim. Reprod. Sci. 81:209-223. https://doi.org/10 .1016/j.anireprosci.2003.10.009.

López-Gatius, F., P. Santolaria, J. Yániz, J. Garbayo, and R. Hunter. 2004. Timing of early foetal loss for single and twin pregnancies in dairy cattle. Reprod. Domest. Anim. 39:429-433. https://doi.org/ 10.1111/j.1439-0531.2004.00533.x.

López-Gatius, F., P. Santolaria, J. Yániz, J. Rutllant, and M. LópezBéjar. 2002. Factors affecting pregnancy loss from gestation Day 38 to 90 in lactating dairy cows from a single herd. Theriogenology 57:1251-1261. https://doi.org/10.1016/S0093-691X(01)00715-4. 
Macdonald, K. A., J. W. Penno, A. M. Bryant, and J. R. Roche. 2005. Effect of feeding level pre- and post-puberty and body weight at first calving on growth, milk production, and fertility in grazing dairy cows. J. Dairy Sci. 88:3363-3375. https://doi.org/10.3168/ jds.S0022-0302(05)73020-4.

Mäntysaari, P., M. Ojala, and E. A. Mäntysaari. 2002. Measures of before and after breeding daily gains of dairy replacement heifers and their relationship with first lactation milk production traits. Livest. Prod. Sci. 75:313-322. https://doi.org/10.1016/S0301 -6226(01)00329-3.

McDougall, S. 2001. Effect of intrauterine antibiotic treatment on reproductive performance of dairy cows following periparturient disease. N. Z. Vet. J. 49:150-158. https://doi.org/10.1080/00480169 .2001 .36223

McDougall, S., F. M. Rhodes, and G. Verkerk. 2005. Pregnancy loss in dairy cattle in the Waikato region of New Zealand. N. Z. Vet. J. 53:279-287. https://doi.org/10.1080/00480169.2005.36561.

McNaughton, L. R., S. R. Morgan, P. Gore, G. A. Verkerk, C. W. Holmes, and T. J. Parkinson. 2002. Monitoring onset of puberty in three genetic strains of Holstein-Friesian dairy cattle. Proc. N.Z. Soc. Anim. Prod. 62:30-33.

McNaughton, L. R., K. M. Sanders, J. E. Pryce, G. E. Bracefield, S. J. Harcourt, and R. J. Spelman. 2007. Phenotypic relationships between the interval from calving to first luteal activity and fertility in a seasonal dairy production system. Anim. Reprod. Sci. 102:98-110. https://doi.org/10.1016/j.anireprosci.2006.10.014.

Meadows, C., P. J. Rajala-Schultz, and G. S. Frazer. 2005. A spreadsheet-based model demonstrating the nonuniform economic effects of varying reproductive performance in Ohio dairy herds. J. Dairy Sci. 88:1244-1254. https://doi.org/10.3168/jds.S0022 $-0302(05) 72791-0$.

Mialon, M.-M., G. Renand, D. Krauss, and F. Ménissier. 2000. Genetic variability of the length of postpartum anoestrus in Charolais cows and its relationship with age at puberty. Genet. Sel. Evol. 32:403-414. https://doi.org/10.1051/gse:2000127.

Morris, C. A., and N. G. Cullen. 1994. A note on genetic correlations between pubertal traits of males or females and lifetime pregnancy rate in beef cattle. Livest. Prod. Sci. 39:291-297. https://doi.org/ 10.1016/0301-6226(94)90291-7.

NZAEL. 2013. DairyNZ. New Zealand Dairy Sire Summary. Accessed Mar. 24, 2016. https://www.dairynz.co.nz/media/581304/NZ _DSS_Introduction_2013.pdf.

Olds, D., and D. M. Seath. 1953. Repeatability, heritability and the effect of level of milk production on the occurrence of first estrus after calving in dairy cattle. J. Anim. Sci. 12:10-14.

Pancarci, S. M., E. R. Jordan, C. A. Risco, M. J. Schouten, F. L. Lopes, F. Moreira, and W. W. Thatcher. 2002. Use of estradiol cypionate in a presynchronized timed artificial insemination program for lactating dairy cattle. J. Dairy Sci. 85:122-131. https:// doi.org/10.3168/jds.S0022-0302(02)74060-5.

Pryce, J. E., M. P. Coffey, and S. Brotherstone. 2000. The genetic relationship between calving interval, body condition score and linear type and management traits in registered Holsteins. J. Dairy Sci. 83:2664-2671. https://doi.org/10.3168/jds.S0022-0302(00)75160 -5 .

Pryce, J. E., M. P. Coffey, and G. Simm. 2001. The relationship between body condition score and reproductive performance. J. Dairy Sci. 84:1508-1515. https://doi.org/10.3168/jds.S0022 $-0302(01) 70184-1$.

Pryce, J. E., and B. L. Harris. 2006. Genetics of body condition score in New Zealand dairy cows. J. Dairy Sci. 89:4424-4432. https:// doi.org/10.3168/jds.S0022-0302(06)72490-0.

Pryce, J. E., and R. F. Veerkamp. 2001. The incorporation of fertility indices in genetic improvement programmes. BSAS Occas. Publ. $237-250$.

Pryce, J. E., R. Woolaston, D. P. Berry, E. Wall, M. Winters, R. Butler, and M. Shaffer. 2014. World trends in dairy cow fertility. Page 680 in Proc. 10th World Congr. Genet. Appl. Livest. Prod., August 17-22, 2014.
R Core Team. 2016. A language and environment for statistical computing. R Foundation for Statistical Computing Vienna, Austria. https://R-project.org/.

Rhodes, F., S. McDougall, S. Morgan, and G. Verkerk. 2001. Supplementing treated anoestrous dairy cows with progesterone does not increase conception rates. N. Z. Vet. J. 49:8-12. https://doi.org/10 .1080/00480169.2001.36195.

Ripley, B. 1987. Stochastic Simulation. John Wiley Sons, New York, NY

Roche, J. R., K. A. Macdonald, C. R. Burke, J. M. Lee, and D. P. Berry. 2007. Associations among body condition score, body weight, and reproductive performance in seasonal-calving dairy cattle. J. Dairy Sci. 90:376-391. https://doi.org/10.3168/jds.S0022 -0302(07)72639-5.

Roelofs, J. B., F. J. C. M. van Eerdenburg, N. M. Soede, and B. Kemp. 2005. Various behavioral signs of estrous and their relationship with time of ovulation in dairy cattle. Theriogenology 63:13661377. https://doi.org/10.1016/j.theriogenology.2004.07.009.

Rottensten, K., and R. W. Touchberry. 1957. Observations on the degree of expression of estrus in cattle. J. Dairy Sci. 40:1457-1465. https://doi.org/10.3168/jds.S0022-0302(57)94656-8.

Roxström, A., E. Strandberg, B. Berglund, U. Emanuelson, and J. Philipsson. 2001. Genetic and environmental correlations among female fertility traits, and between the ability to show oestrus and milk production in dairy cattle. Acta Agric. Scand. A Anim. Sci. 51:192-199. https://doi.org/10.1080/09064700118617.

Royal, M., G. E. Mann, and A. P. F. Flint. 2000a. Strategies for reversing the trend towards subfertility in dairy cattle. Vet. J. 160:53-60. https://doi.org/10.1053/tvjl.1999.0450.

Royal, M. D., A. O. Darwash, A. P. F. Flint, R. Webb, J. A. Woolliams, and G. E. Lamming. 2000b. Declining fertility in dairy cattle: Changes in traditional and endocrine parameters of fertility. Anim. Sci. 70:487-501.

Royal, M. D., A. P. F. Flint, and J. A. Woolliams. 2002a. Genetic and phenotypic relationships among endocrine and traditional fertility traits and production traits in Holstein-Friesian dairy cows. J. Dairy Sci. 85:958-967. https://doi.org/10.3168/jds.S0022 -0302(02)74155-6.

Royal, M. D., J. E. Pryce, J. A. Woolliams, and A. P. F. Flint. 2002b. The genetic relationship between commencement of luteal activity and calving interval, body condition score, production, and linear type traits in Holstein-Friesian dairy cattle. J. Dairy Sci. 85:30713080. https://doi.org/10.3168/jds.S0022-0302(02)74394-4.

Schäfer, J., R. Opgen-Rhein, V. Zuber, M. Ahdesmäki, A. P. D. Silva, and K. Strimmer. 2015. Corpcor: Efficient estimation of covariance and (partial) correlation. http://strimmerlab.org/software/ corpcor/.

Smith, B. A., J. S. Brinks, and G. V. Richardson. 1989. Estimation of genetic parameters among reproductive and growth traits in yearling heifers. J. Anim. Sci. 67:2886-2891.

Smith, M. C., and J. M. Wallace. 1998. Influence of early post-partum ovulation on the re-establishment of pregnancy in multiparous and primiparous dairy cattle. Reprod. Fertil. Dev. 10:207-216.

Spicer, L. J., W. B. Tucker, and G. D. Adams. 1990. Insulin-like growth factor-I in dairy cows: Relationships among energy balance, body condition, ovarian activity, and estrous behavior. J. Dairy Sci. 73:929-937. https://doi.org/10.3168/jds.S0022-0302(90)78749-8.

Sreenan, J. M., and M. G. Diskin. 1986. The extent and timing of embryonic mortality in the cow. J. M. Sreenan and M. G. Diskin, ed. Springer, Dordrecht, the Netherlands.

Stachowicz, K., G. Jenkins, P. Amer, and S. Meier. 2015a. New approaches to fertility evaluation in a seasonal calving system. Interbull Bull. 48:89-93.

Stachowicz, K., G. M. Jenkins, P. R. Amer, J. R. Bryant, and S. Meier. 2015b. Proposed changes in the genetic evaluation of dairy fertility in New Zealand. Proc. Assoc. Advmt. Anim. Breed Genet. 21:370-373.

Taylor, K., C. M. Small, M. P. Epstein, M. L. Terrell, and M. Marcus, 2009. Heritability of age at menarche and menstrual cycle length 
in a population exposed to a brominated flame retardant. Int. J. Child Adolesc. Health 2:383-394.

Vallimont, J. E., C. D. Dechow, J. M. Daubert, M. W. Dekleva, J. W. Blum, C. M. Barlieb, W. Liu, G. A. Varga, A. J. Heinrichs, and C. R. Baumrucker. 2010. Genetic parameters of feed intake, production, body weight, body condition score, and selected type traits of Holstein cows in commercial tie-stall barns. J. Dairy Sci. 93:4892-4901. https://doi.org/10.3168/jds.2010-3189.

Vasconcelos, J. L. M., R. Sartori, H. N. Oliveira, J. G. Guenther, and M. C. Wiltbank. 2001. Reduction in size of the ovulatory follicle reduces subsequent luteal size and pregnancy rate. Theriogenology 56:307-314. https://doi.org/10.1016/S0093-691X(01)00565-9.

Veerkamp, R. F., and B. Beerda. 2007. Genetics and genomics to improve fertility in high producing dairy cows. Theriogenology 68(Supplement 1):S266-S273. https://doi.org/10.1016/j theriogenology.2007.04.034

Veerkamp, R. F., P. Dillon, E. Kelly, A. R. Cromie, and A. F. Groen. 2002. Dairy cattle breeding objectives combining yield, survival and calving interval for pasture-based systems in Ireland under different milk quota scenarios. Livest. Prod. Sci. 76:137-151. https:// doi.org/10.1016/S0301-6226(02)00006-4.

Veerkamp, R. F., E. P. C. Koenen, and G. De Jong. 2001. Genetic correlations among body condition score, yield, and fertility in firstparity cows estimated by random regression models. J. Dairy Sci. 84:2327-2335. https://doi.org/10.3168/jds.S0022-0302(01)74681 -4 .

Veerkamp, R. F., J. K. Oldenbroek, H. J. Van Der Gaast, and J. H. J. V. D. Werf. 2000. Genetic correlation between days until start of luteal activity and milk yield, energy balance, and live weights. J. Dairy Sci. 83:577-583. https://doi.org/10.3168/jds .S0022-0302(00)74917-4.

Venables, W. N., and B. D. Ripley. 2002. Modern Applied Statistics with S. 4th ed. Springer, New York, NY.

Warnes, G. R., B. Bolker, G. Gorjanc, G. Grothendieck, A. Korosec, T. Lumley, D. MacQueen, A. Magnusson, J. Rogers, and others. 2015. Gdata: Various R programming tools for data manipulation. https://cran.r-project.org/web/packages/gdata/index.html.

Wickham, H. 2007. Reshaping data with the reshape package. J. Stat. Softw. 21:1-20

Wickham, H. 2011. The split-apply-combine strategy for data analysis. J. Stat. Softw. 40:1-29.

Winkelman, A. M., R. M. Wood, and B. L. Harris. 2010. Enhancement of calving difficulty breeding values in New Zealand. Interbull Bull. 42:91-94.

Xu, Z. Z., and L. J. Burton. 2003. Reproductive performance of dairy cows in New Zealand. Accessed Mar. 27, 2014. http://www .lic.co.nz/user/file/Monitoring\%20fertility\%20report\%20for\% 20 distribution.pdf.

Xu, Z. Z., D. J. McKnight, R. Vishwanath, C. J. Pitt, and L. J. Burton. 1998. Estrus detection using radiotelemetry or visual observation and tail painting for dairy cows on pasture. J. Dairy Sci. 81:2890-2896. https://doi.org/10.3168/jds.S0022-0302(98)75849 -7 . 